\title{
Time as Norm: The Ritual Dimension of the Calendar Book and the Translation of Multi-Temporality in Late Imperial China
}

\author{
Fupeng Li
}

The Great Voyage not only triggered the geographical connectivity of the Iberian Peninsula to the world, but also brought about a global reconciliation of temporal order through the circulation of Western astronomical knowledge. ${ }^{1}$ In the face of intercultural encounters between China and the Iberian empires, two types of normative knowledge were spread by missionaries, but with diametrically opposed outcomes in the Chinese context, thus forming a tale of two cities: Portuguese Macau and Beijing, concerning religion and science, respectively. ${ }^{2}$ In contrast to the prohibition of Christianity due to the Rites Controversy over the religiosity of Confucianism, ${ }^{3}$ the scientific knowledge of astronomy was incorporated into Chinese traditional ritual practices by the Jesuits serving at the imperial court, in the formulation of calendar books, after the German Jesuit Adam Schall von Bell (1591-1666) was appointed as director of the Imperial Observatory (欽天監) in 1644 .

By focusing on the distinct ways of marking time in China and Christianity, this chapter, first, demonstrates the differences between the two genres of knowledge-Jesuit astronomy and traditional Chinese numerology-by revisiting the calendrical controversies during the late Ming and early Qing dynasties so as to redefine the Chinese calendar as a manual of rituals for guiding the actions and decision-making process of daily life. Second, the chapter

1 For a representative study on temporal order in late imperial China, see Struve (ed.), Time, Temporality, and Imperial Transition. For the overview of the exchange of scientific knowledge between China and the Jesuits, see Zhang, Making the New World Their Own; Deiwiks et al. (eds.), Europe meets China, China meets Europe. On studies of mathematics and cartography related to Jesuit astronomy, see Jami, The Emperor's New Mathematics; Smith, Mapping China and Managing the World.

2 Hsia, "Christianity and Empire", 213, 218.

3 For a comparative study on rites controversies from a global perspective, see Županov and Fabre (eds.), The Rites Controversies in the Early Modern World. 
further discusses how the Chinese calendar constructs a synthesis of multiple orders - the natural order of unifying the universe/heaven and man, the imperial order of spatial integration, and the life order of ordinary people-by incorporating Chinese or Jesuit knowledge into ritual practice. Finally, in terms of the regime of temporality, this chapter goes on to explore how the encounter between China and the Iberian empires not only shaped the segregation, coexistence, and overlapping of multiple communities of time, depending on various ritual rhythms, but also opened up another perspective on approaching global legal history as a translation process of normative knowledge between multi-temporalities.

\section{2 \\ Between Time and Ritual: Revisiting Calendar Controversies}

The Jesuit global mission to China coincided with the dramatic change of Chinese dynasties from the Ming to the Qing, established by the Manchus. Not only did the Jesuits contribute valuable historical records of this transition period from the external perspective, for instance, Martino Martini's De Bello Tartarico Historia (Antwerp, 1654), but, within the Chinese Empires, Jesuit astronomer Schall also took advantage of this shifting moment to serve the Imperial Observatory, thus approaching the Chinese imperial power through the making of calendar books.

By revisiting calendar controversies in which the Jesuits were deeply involved, including the calendar reform in the late Ming dynasty (2.1) and the calendar case in the early Qing dynasty (2.2), this section discusses the different genres of knowledge regarding heaven, among Portuguese Jesuits and Chinese literati, so as to provide insight into why the imperial calendar book could be considered part of a ritual manual of normative knowledge based on mantic techniques for guiding human behavior (2.3).

\subsection{Calendar Reform in the Late Ming Dynasty (1629-1644)}

The calendar has always been of supreme political and symbolic significance in traditional China. This was especially true for each newly established dynasty, which had to correct the first day of the lunar month (改正 朔), typically by issuing a new calendar in the name of the founding emperor to mark the beginning of a new order after the chaos within the eternal cosmic cycle. ${ }^{4}$ This appears to be why the reform of calendar, repeatedly

4 On the religious and political significance of calendars in the Chinese context, see Ge, $A n$ Intellectual History of China, 61. Jami, The Emperor's New Mathematics, 33. 
proposed between 1596 and 1611 in the late Ming dynasty, became urgent due to the significant increase in inaccuracies of the Great Concordance Calendar (大統曆), based on the Muslim astronomical system, resulting in a growing discrepancy between the calculations of eclipses and actual observations, as well as the underlying crisis of symbolic legitimacy. ${ }^{5}$ It was in the second year (1629) after the final Ming emperor's assumption of the throne that another significant error in predicting a solar eclipse occurred, prompting Emperor Chongzhen (1628-1644) to order the Vice-Minister of Rites, Chinese Christian scholar-official Paul Xu Guangqi (1562-1633), to open the Calendar Bureau (曆局) for a revision of the calendar. ${ }^{6}$

As one of the so-called 'Three Pillars of Chinese Catholicism', Xu invited Jesuits Johannes Schreck (1576-1630), Niccolò Longobardo (1565-1654), and, later, Giacomo Rho (1593-1638), along with Schall to be his European collaborators. ${ }^{7}$ From 1629 to 1634 , they translated and compiled the works of Nicolaus Copernicus, Johannes Kepler, and Galileo Galilei, etc., archiving a new epistemic body of celestial knowledge, well-known as The Calendrical Treatises of the Chongzhen Reign (崇禎曆書). ${ }^{8}$ In this way, not only did the Jesuits complete a paradigm shift through the global circulation of Western astronomical knowledge, but they also formed an epistemic community primarily composed of missionaries and baptized Chinese scholar-officials within the Calendar Bureau, who actively engaged in the calendar reform.

In the face of fierce controversies over the different models based respectively on the official Great Concordance Calendar, the Muslim system, the new Western method, and Wei Wenkui's method, the Chongzhen Emperor insisted on "achieving uniformity" (務求劃一), ${ }^{9}$ thereby leaving the absence of a new calendar until the collapse of the Ming dynasty. This impossible demand for synthesis, along with the emperor's extremely pronounced prudence, goes far beyond a purely technical discussion, shedding light on the specificity of knowledge concerning how to understand, systematize, and interpret the celestial phenomena in the Chinese context.

On the one hand, the political and religious facets of the Chinese calendar were repeatedly articulated in the imperial edicts of the Chongzhen Emperor. For instance, in an edict to $\mathrm{Xu}$ in 1629 , the emphasis was placed on his role as

5 For the historical background of the calendar reform of the Ming dynasty, see Peterson, "Calendar Reform Prior to the Arrival of Missionaries at the Ming Court".

6 On Xu's role in the calendar reform, see Hashimoto, Hsü Kuang-ch'i and Astronomical Reform, 7-73; Hashimoto and Jami, "From the Elements to Calendar Reform".

7 For a background on Jesuit astronomers, see Collani, "Astronomy versus Astrology", 423-424.

8 For a media perspective of the Calendrical Treatises, see Chu, "Archiving Knowledge".

$9 \mathrm{Xu}$, Zhi Li Yuan Qi, 1602. 
a Sage King for his divine sensation of heaven by modeling a timing sequence reverently following the celestial order (朕惟授時欽若, 王者所以格天). ${ }^{10} \mathrm{On}$ the other hand, and of more significant concern to legal historians, was the way in which the normative role of the calendar was treated by different epistemic communities. Chinese scholars generally categorized the Jesuit techniques of calculating, observing, and predicting the heavenly phenomena as a kind of practical learning (实学), ${ }^{11}$ which addressed the tangible things of material life but failed to serve a pragmatic use of calendar crucial for the formation and the maintenance of normative orders in everyday life. ${ }^{12}$

However, Chinese Christian Li Tianjing (1579-1659), who succeeded Xu in charge of the Calendar Bureau in 1633, insisted on the Western method without compromise. This was, of course, partly due to the technical inconsistency between different models, but also disclosed a deliberately hidden religious intent, ${ }^{13}$ which surfaced in the period of transition from the Ming to the Qing dynasty. In 1645, Schall presented the Calendrical Treatises of the Chongzhen Reign to the new rulers after renaming it the Calendrical Treatises in Accordance with the New Western Methods (西洋新法曆書). Through an archive reconstruction, Jesuits replaced China with the West, as well as old ways with new methods, in an attempt to establish a new orthodoxy beyond the technological dimension. ${ }^{14}$ This, however, brought about the externalization and intensification of the calendar controversies which, in turn, led to the calendar case in the Kangxi reign in early Qing China explored below.

\subsection{The Calendar Case in the Early Qing Dynasty (1664-1669)}

In May 1644, Qing troops conquered the city of Beijing, prompting Schall to turn his missionary hopes over to the Qing court. He presented his astronomical predictions, based on the Ptolemaic system, to the Manchu prince and regent Dorgon (1612-1650), and was thus appointed to produce new astronomical instruments and a new calendar for the new rulers. From 1645 until the end of the 18th century, the Qing dynasty relied on the Jesuits, ${ }^{15}$ along with

$10 \quad \mathrm{Xu}$, Zhi Li Yuan Qi, 1547, 1599.

11 On the concept of practical learning, Jami, The Emperor's New Mathematics, 31.

12 On the different uses of pragmatic literature and practical literature between legal history and history of science, see Duve, "Pragmatic Normative Literature and the Production of Normative Knowledge", 24-25.

13 The religious purpose of the Jesuits can be gleaned from their letters to the Jesuits in Rome. See Collani, "Astronomy versus Astrology", 446.

14 Chu, "Archiving Knowledge".

15 On the power struggle within the Imperial Observatory, especially with Muslim astronomers, see Huang, "Qingchu Qintianjian zhong ge Minzu Tianwenjia de Quanli Qifu”; Huang, “Qingchu Tianzhujiao yu Huijiao Tianwenjia de Douzheng”. 
the new Western methods, to produce the officially issued Temporal Model Calendar (時憲曆/書). ${ }^{16}$ Its name was taken from the Confucian classic Shangshu, which stated that only the Sage King could model the heaven for marking time (惟聖時憲), highlighting the political intentions of the Manchu regime on reconstructing legitimacy for the vast majority of Han Chinese. During this long-lasting collaboration between Western technology and imperial symbols, there was only one brief interruption, the calendar case in the Kangxi reign (1664-1669), ${ }^{17}$ which led to the resurgence of the Ming great concordance calendar (1666-1668) and the Muslim system (1669). ${ }^{18}$ It was the most significant anti-Christian case in the early Qing dynasty, which not only attacked Jesuit astronomers, severely hindering the missionary enterprise in China, but also shed light on different types and uses of celestial knowledge.

Concerning the causes that led to this calendar case, scholars have proposed various interpretations, ranging from power struggles within the court to religious rivalries and private jealousies. ${ }^{19}$ In any case, however, almost all relevant research must confront two core allegations against Schall. The first charge results from the phrase printed on the title page of the calendars: "Temporal Model Calendar printed by the Imperial Observatory according to the new Western method and promulgated throughout the empire" (欽天 監依西洋新法印造時憲曆日頒行天下). The expression of the new Western method was seen by Yang Guangxian (1597-1669) as threatening the legitimacy of the new empire. However, another more serious, accusation by Yang directly blamed the Astronomical Bureau for prescribing an inauspicious time for the burial of Prince Rong, which led to potential misfortune for the imperial family. Emperor Shunzhi and Rong's mother also died of smallpox shortly afterwards. ${ }^{20}$

After a sudden earthquake in Beijing, believed to be a warning from heaven, Schall and three other Jesuits were released from their death sentences. Accordingly, those with a death sentence were committed to house-arrest in Beijing. Other missionaries, however, did not have such fortune. While five Christian

16 On the process of orthodoxizing the Western calendar system, see Huang, "Tang Ruowang yu Qingchu Xili zhi Zhengtonghua".

17 For a summary of the calendar case, see Dudink, "Opponents", 513-515.

18 Chunhua, "Lun Qingdai Banfa Hanwen Shixianshu Shimo", 170.

19 For a comprehensive review of this topic, see Jami, "Revisiting the Calendar Case". The use of the Manchu archives is particularly helpful for exploring the details of dynamics of power within the court. See Deiwiks, "The Secret Manchu Documents on the Trial of Jesuit Missionary Johann Adam Schall”; An, "Tang Ruowang An Shimo"; An, "Tang Ruowang zai Hua Chuanjiao zhi De yu Shi".

$20 \quad$ Huang, "Selection of Auspicious Dates and 'Calendar Lawsuit' in the K'ang-his Reign Period", 2o-26; Menegon "Yang Guangxian's Opposition to Johann Adam Schall”. 
astronomers in service to the Imperial Observatory were executed previously, numerous Catholic missionaries residing in the provinces were repatriated to Macau. $^{21}$

The core controversy in this case can be revisited and reinterpreted from a legal-historical perspective. There is a growing body of research that goes beyond the overemphasis on the universality of Western science within the history of science ${ }^{22}$ or a focus on the morality in the field of the Christian mission, ${ }^{23}$ focusing instead on the relationship between knowledge, rituals, social-political orders, and the techniques of imperial governance in the context of late imperial China. Focusing on hemerology and divination, for example, Huang argues that Schall and his confreres were in fact being judged for the policy of their Church by exerting authority over popular culture, which Chinese rulers saw as undermining the government rituals and popular values that were embodied in the making of calendars. ${ }^{24}$ Similarly, Chu argues that the dispute "was perhaps less about who was in the proper position to organize knowledge than about who was in a proper position to organize the social order". ${ }^{25}$ From a legal-historical perspective, the controversy was thus also less about conflicting visions about science and more about determining who had the authority to give the norms and values of everyday life.

There is also the potential for convergence between different types of knowledge. According to Catherine Jami's research, Ferdinand Verbiest's demonstration of his advanced astronomical skills in 1669 not only led to the rehabilitation of Jesuit astronomy, but also enabled the Jesuits to return to be the emperor's court, since the Kangxi Emperor was deeply aware that astronomical knowledge was a necessary technique of governance for achieving the integration of the multiple orders of the empire. ${ }^{26}$ Therefore, the making and application of the Temporal Model Calendar is a case that should be revisited as it combines and entangles two kinds of pragmatic knowledge that were crucial for the governance of the Qing empire in the early modern world: the practical learning of Western science and the normative density of Chinese rituals.

\footnotetext{
21 Collani, "Astronomy versus Astrology", 452-453. Jami, "Revisiting the Calendar Case", 462.

22 Needham, Science and Civilisation in China, 449-450.

23 Dunne, Generation of Giants, 221-222, 260.

24 Huang, "Court divination and Christianity", 17-18.

25 Chu, "Scientific Dispute", 31.

26 On the Kangxi Emperor's emphasis on Western learning, see Jami, The Emperor's New Mathematics, 239-259.
} 


\subsection{The Calendar as a Manual of Rituals}

The calendar controversies, not least the calendar case of Schall, thus underline the tension between two intellectual traditions performed by various epistemic communities - the doctrines of the Catholic Church for astrology or divination and the traditional numerology handed down by Chinese calendrical experts (疇人) - with regard to the means of constructing social and imperial orders, through the practice of everyday life, especially in the context of the empire formation in the Qing dynasty. Of course, both parties to the dispute had been striving to observe, understand, and, to some extent, adjust their own intellectual and political positions so as to distinguish or accommodate the knowledge of their counterparts, as manifested in the Chinese calendar book. It is therefore necessary to analyze the use of the two kinds of knowledge in the calendar carefully, as well as how they jointly structured the ritual orders within the Qing empire.

From the perspective of the Society of Jesus, Claudia von Collani summarizes this above-mentioned intellectual tension as "Astronomy versus Astrology". Not only do the challenges come from Chinese official scholars, but also from other Jesuits and the Catholic Church based on the established definition of superstition even after the Council of Trent. One of the most representative criticisms, fiercely represented by the treatise of the Portuguese Jesuit Gabriel de Magalhães (1610-1677), argued that Schall had departed from the Christian faith by virtue of the superstition and divination contained in the calendar book for which he was responsible. ${ }^{27}$ While Schall absolves himself from blame by distinguishing between two different elements of calendar books, Verbiest attributes what is called superstition by Magalhães to certain kinds of folk customs originating in Chinese traditions, which serves to place the public welfare in harmony with the natural order, providing a template from which to select auspicious dates for important events of daily life, such as when to marry, conclude a contract, or carry out a ritual. ${ }^{28}$ Similarly, when facing the Chinese official scholars, Schall and Verbiest, in their book Enlightening the Bewildered Regarding the Commentary in the Civil Calendar (民曆鋪註解惑), clarify that the annotations on the calendar about good fortune and bad luck were not based on the new Western calendar system, but were merely the preservation of Chinese customs that contributed to the moralization of the

27 Collani, "Astronomy versus Astrology", 431-432.

28 Collani, "Astronomy versus Astrology", 445-447. For Ferdinand Verbiest's criticisms of Chinese mantic arts, see Chu, "Against Prognostication". 
people by gradually internalizing a grand imperial order in every state, in every family, and in the body of every subject (化天下為一國, 化一國為一家, 化 一家為一身). ${ }^{29}$

By reframing the genealogy of Chouren, Chinese traditional astronomical experts in the Qing dynasty, Chu Pingyi refers to these two kinds of knowledge as "Numerology and Calendrical Learning". Although the epistemic community of Chouren were aware of Yang Guangxian's technical inferiority in astronomy compared to the Jesuits, they still insisted that the mantic function, based on Chinese numerological tradition, was more critical to the use of an almanac for daily decision-making. ${ }^{30}$ Thus, in addition to the ongoing potential for technical competition, the Jesuits, in collaboration with their Chinese partners in the Imperial Observatory, produced a hybrid form of calendar by employing three major Chinese mantic arts: astrology, geomancy, and genethlialogy. ${ }^{31}$

Despite endorsing a way of making calendars that reconciled these two kinds of knowledge, imperial rulers were still apprehensive about the divergent views on the traditional mantic arts. In other words, having unified the method of calculating time, they also wanted to unify the way of marking time. Accordingly, with regard to Chinese numerology, the Qing court published three books as the official standard: the Almanac for Day Selection (選擇通書, 1683) and the Imperially Approved Investigations into Stars and the Calendar (欽定星曆考原, 1713) in the Kangxi reign and the Imperially Approved Treatise on Harmonizing the Times and Distinguishing the Directions(御制協紀辨方書, 1741) in the Qianlong reign. ${ }^{32}$ In the preface to the last book, Emperor Qianlong explicitly stated that the key to good and bad fortune did not lie in the mantic technique, but rather existed between "respect and disrespect", thereby shaping a centralized authority of imperial governance through the use of calendars to arrange the daily lives of the people.

In short, the Jesuits, the Chinese Chouren, and the new rulers of the new empire all clearly perceived the conflict between these two types of knowledge and epistemic communities. However, whether for religious or political purposes, they all acknowledged, to some extent, the validity of each other's knowledge, especially by connecting Chinese mantic arts to normative concepts, such as custom, ritual, and order. It is in this sense that the calendar book could be conceived as a container of normative knowledge that not only served the spatial governance of an ever-expanding empire, but also

29 Schall von Bell, Minli Puzhu Jiehuo, 8.

$30 \quad \mathrm{Chu}$, "Numerology and Calendrical Learning", 483.

$31 \quad$ Chu, "Numerology and Calendrical Learning", 488.

32 Smith, "The Legacy of Daybooks in Late Imperial and Modern China", 337. 
functioned as a pragmatic manual of rituals that instructed the ways different roles within the Qing empire were to be performed.

\section{The Calendar and Its Multiple Orders}

As a manual of rituals, the Qing calendar book acted as a hub of knowledge that oriented behaviors and decision-making. In every official almanac, Jesuit astronomy and traditional Chinese numerology were integrated into the Chinese rituals, creating multiple overlapping orders of different layers, ranging from imperial governance to daily life. The first layer was a cosmogony of unifying and harmonizing the universe/heaven and man (天人合一), symbolized primarily in the Diagram of the Position of the Sprits for the year (年神 方位之图), which very distinctly shows the principles of how to arrange life in the coming year based on the operation of the natural order (3.1). The second layer was the secular order, "All under Heaven" (天下), simply understood as the imperial order, embodied mainly in a system of issuing the official calendar of 24 seasonal markers of time (节气) to the locals inside and outside the Qing empire, following Jesuit cartography and astronomy (3.2). Finally, there was a layer of life order, consisting of various individual or collective behaviors mainly in the form of daily predictions of good or bad fortune throughout the year (3.3).

\subsection{The Natural Order of Heaven and Man}

A quasi-religious relationship between the universe/heaven and human beings underpins the fundamental assumptions of Chinese self-conception. Briefly stated, both Confucian and Taoist Chinese philosophical thought generally holds that human beings share the same nature as the universe/heaven. Thus, the secular life should conform to the natural rhythm, a sexagenary cycle formed by the movement of heaven and earth, which serves as the ritual foundation for making a Chinese calendar. ${ }^{33}$ This section focuses on the Diagram of the Position of the Spirits for the Year (年神方位之图) and other markers for recording significant dates typically attached before or after the death days of emperors and empresses, birthdays of the gods, and celestial signs for good or bad fortune. ${ }^{34}$

33 See Smith, "The Chinese Sexagenary Cycle and the Ritual Origins of the Calendar", especially $22-23,25,26$.

34 For a material perspective on the relationship between text and image in Chinese calendars, see Arrault, "Les calendriers chinois: l'image du temps, le temps dans les images". 
Due to the limitations of the subject matter, a comprehensive explanation of the details of this diagram of the year cannot be offered, ${ }^{35}$ however it can be emphasized that it represents an earthly mirroring of celestial operations by placing the course of time into a certain kind of spatial guidance. For example, among the 24 directional units of the external circle, the four most prominent corners represent four directions of the sprits of the year, namely, Memorialist (奏書) standing for honor, Erudite (博士) for fair, Strongman (力士) for foul, and Silkworm (䖯室) for disaster. Therefore, according to the Chinese tradition shown in the calendar, if someone plans to lay a foundation or build a house, they should by all means choose an auspicious position or avoid an inauspicious direction. To this, the almanac provides more detailed guidance, but need not be mentioned further here.

Another group of guidelines for daily life are printed in red, either at the beginning of the book or attached to the diagram of the year. The content varies slightly depending on the version, but almost always includes three types, in order of dates of emperors' and empresses' deaths, birthdays of the gods, and celestial signs of good or bad fortune. ${ }^{36}$ The combination of these three types of information is well worth discussing, not least for understanding how Qing rulers reinforced their legitimacy by incorporating themselves into a collective memorial system. First, the anniversary of the death of the supreme rulers was ritualized by making it a national day of commemoration, with a strict prohibition on pleasure seeking, celebrating weddings and assuming office. Second, the sacralization of the secular order was achieved through the juxtaposition of the imperial rulers with the birthdays of the gods, primarily consisting of the major Buddhist and Taoist festivals. Finally, both the death days and the birthdays are rationalized again by being integrated into the system of celestial signs. This placed the Qing emperors as communicators between heaven and their subjects, thereby securing a proper order.

\subsection{Representing a Unified Imperial Order}

With the use of Jesuit cartographic and astronomical knowledge, the Qing calendars included a timetable for sunrise and sunset composed of 24 seasonal markers pertaining to different localities, from the capital Beijing, local

35 For a more detailed explanation of this diagram, see Smith, "The Legacy of Daybooks in Late Imperial and Modern China", 349-351; Smith, Chinese Almanacs, 10-13.

36 According to the Qing calendars collected in Harvard-Yenching Institute, this juxtaposition had already begun during the Qianlong reign. But by the Guangxu reign in the late Qing, the calendars retained only the national jubilees, while leaving out the birthdays of the gods. See Harvard-Yenching Library Collection, T719o.8/635o (1790, 1793, 1883). 
provinces, and frontier regions to the tributary states, such as Korea and Ryukyu/Okinawa. This exemplifies how Western "practical learning" could be used in the service of Qing imperial governance. For instance, an imperial project of mapping the Atlas of the Chinese Empire (康熙皇舆全覽圖) from 1708 to 1718 was mainly carried out by French Jesuit Jean-Baptiste Régis (?-1738) and Joachim Bouvet (1656-1730), with the support of the Kangxi Emperor. ${ }^{37}$ Moreover, through a system of issuing the official calendar that extended from the Forbidden City to the imperial peripheries and the tributary states, the Qing calendars have consistently translated Jesuit knowledge into ritual practices, thus presenting the ongoing process of integration of the multinational empire of Qing, the relationship between imperial center and peripheries, and even the evolution of the tributary system as the territory of the Qing empire continued to expand.

The gradual increase in the number of regions covered in the official calendars is consistent with the expansion of the Qing Empire, primarily taking place during the Kangxi and Qianlong reigns. The restitution of the Jesuit Verbiest as head of the Astronomical Bureau ended the calendar case (1664-1669) and marked the beginning of the Kangxi Emperor's personal rule over the empire. After settling the internal revolt of the three feudatories (1673-1681), the Kangxi Emperor succeeded in conquering the Mongols. Accordingly, by imperial decree, 24 new regions (mainly of the Khalkha Mongol of the north) were added to the timetable of the official calendar in 1692/1693. Another 15 new regions (mainly including the Dzungar Khanate of the west and Hami) were included in the calendar in 1713. In addition to continuing to consolidate the northwest, the Qianlong Emperor suppressed the Jinchuan Hill Peoples in the southwest, thus listing 13 new regions in $1777 \cdot^{38}$

Within the tribute system, Chosŏn/Korea was already listed in the Qing calendar of 1645; Annam/Vietnam and the Ryukyu were included in the official calendars in 1789 and 1809 respectively due to their request for the issuing of the official calendars. However, other vassal states like Siam, Burma, Sulu, and Lan Xang were never mentioned in the calendars. In short, interior provinces, newly conquered frontiers, and tribute states were all arranged according to their longitudes on the map from Shengjing downwards (各省序次盛京而下 悉依地圖地之經度所列), Shengjing being the birthplace of the Manchu Qing, so as to construct the image of a unified imperial territorial order. Moreover,

37 See Ribeiro and O'Malley (eds.), Jesuit Mapmaking in China.

38 For the official record of the addition of regions in the Great Qing Collected Statutes (大清会典), as well as its representation in the calendars, see Chunhua, "Lun Qingdai Banxingli 'Shikebiao' nei de Diming Tedian”, 449-457. 
as shown in the official calendar of $1883^{39}$ Vietnam and the Guizhou province and Korea and the Jilin province were juxtaposed in the same space, in a way that blurred or dissolved the spatial distinction between the inside and the outside of the empire. It was intended to leave people with a general impression of all-under-heaven (天下), along with the widespread practice of rituals for issuing the official calendar within the empire.

Every year, on the first day of October, the ceremony of issuing the official calendar was solemnly conducted outside the Meridian Gate of the Forbidden City. Participants were limited to the emperor, princes, nobles, and high officials in the capital. The promulgated calendars were available in Manchu, Mongolian, and Chinese languages. ${ }^{40}$ The officially issued calendars would then be distributed throughout the empire, reaching the counties as the lowest administrative bodies. Additionally, the Board for the Administration of Outlying Regions (理藩院) forwarded the calendars to the Mongolian feudatories while the Ministry of Rites (禮部) transmitted them to the tributary states. ${ }^{41}$ For instance, according to the archives of the Nanbu county (南部縣) of Sichuan province, a county would be assigned 2,00o copies of the civil calendar, which would then be further handed out by the local official in charge of rites to local communities of practice in religious, social, and economic fields, such as monks, Taoists, yin-yang masters/geomancers, medical practitioners, clan associations (會總), and so on, ${ }^{42}$ so as to guide ordinary people's behavior and decision-making in their daily lives.

\subsection{A Life Order of Shaping Individual and Collective Behavior}

As noted above, Jesuit astronomers explicitly denied that the daily annotations in the calendar were of their own making, instead ascribing them to traditional Chinese customs and rituals for the sake of public welfare-a soft form of governance that internalized the imperial order into individual behavior through daily decision-making. According to the Imperially Approved Treatise on Harmonizing the Times and Distinguishing the Directions, there were 67 items, 30 for imperial use and 37 for civilian use, basically covering all essential aspects of the daily life of the emperor or the ordinary person. These matters constituted a ritualized setting of daily life in a traditionally calculated manner concerning the motion of celestial bodies.

\footnotetext{
39 Harvard-Yenching Library Collection, T719o.8/6350 (1883).

40 Chunhua, "Lun Qingdai Banfa Hanwen Shixianshu Shimo", 171.

41 For a more detailed analysis of the relationship between calendars and the territory of the Qing dynasty, see Wang, "Calendar Books of the Qing Dynasty and the Formation of a Modern, Unified and Multinational China”, 198-203. 
As for the 37 civilian matters, they not only set out the critical affairs that every ordinary person may encounter during the year, but also formed a cycle of life, from ancestor-worship to burial, including the rituals for different stages of life (schooling, coming of age, and marriage), the care of one's body and security (bathing, healing, and traveling), the maintenance of real estate (laying foundations, construction, and renovation), and commercial and agricultural practices (contracting, trading, and planting). These and other rituals are illustrated in Table 10.1, below. ${ }^{43}$ Similarly, the additional 30 matters for imperial use mainly focused on the requirements of being a good emperor. These included, for instance, internal selection and appointment (appointing ministers, recruiting the virtuous, and elevating the righteous), diligent governance and caring for the people (compassion for the weak, correcting injustices, and delaying punishment), and external military affairs (pacifying borders, selecting generals and training soldiers, and sending out troops) ${ }^{44}$

In this sense, the calendar transformed the year's life, either of the emperor or the ordinary person, into time-based rituals. Moreover, through a cyclical view of time and history, the practice/performance of major matters was strung together into a ritualized life for individuals. Of course, the rules in the calendar should not be rigidly applied to imagine people's daily behaviors, for the practice of living always reflects, to a great or lesser extent, discrepancies with norms. For instance, in a calendar of 1873 used by a village doctor, he clearly recorded going out to visit a patient on days when travel was not advisable. Of course, major country ceremonies still strictly followed specific dates, such as the ritual performance for sending away the god of plague. It is clear that ordinary people were always inclined to compare, control, and modify their behaviors in concrete settings and to pursue the favorable and avoid the unfavorable. Undoubtedly, traditional Chinese calendars, as a kind of ritual manual or index, ${ }^{45}$ set up the most noteworthy aspects of this underlying scenario of Chinese life with several limiting premises.

\section{$4 \quad$ Regimes of Temporality in Global Legal History}

Based on the above analysis of the multiple orders embodied in the official Chinese calendars, this concluding section explores further how the calendar understood as a manual of rituals, shaped the communities of time during China's encounter with Christianity (4.1). In addition, through the lens of

\footnotetext{
43 Yuzhi Xieji Bianfang Shu, vol. 11, 2b-3b.

44 Yuzhi Xieji Bianfang Shu, vol. 11, 1b-2b.

45 Smith, Chinese Almanacs, 2.
} 
TABLE 10.1 Thirty-seven Matters about Civil Life according to the Imperially Approved Treatise on Harmonizing the Times and Distinguishing the Directions

\begin{tabular}{|c|c|c|}
\hline No. & English & Chinese \\
\hline $\mathrm{O} 1$ & Offering sacrifices to gods/ancestors & 祭祀 \\
\hline $\mathrm{O} 2$ & Presenting a memorial to gods/emperor & 上表章 \\
\hline $\mathrm{O} 3$ & Taking up an official position & 上官 \\
\hline $\mathrm{O} 4$ & Starting school & 入学 \\
\hline 05 & Coming-of-age ceremony & 冠带 \\
\hline o6 & Engagement & 結婚姻 \\
\hline 07 & Visiting friends and relatives & 會親友 \\
\hline o8 & Wedding & 嫁娶 \\
\hline o9 & Increasing family members & 進人口 \\
\hline 10 & Traveling & 出行 \\
\hline 11 & Moving to a new house & 遷徙 \\
\hline 12 & Installing a new bed & 安牀 \\
\hline 13 & Bathing & 沐浴 \\
\hline 14 & Barbering & 剃頭 \\
\hline 15 & Healing & 療病 \\
\hline 16 & Tailoring clothes & 裁衣 \\
\hline 17 & Construction or laying foundations & 修造動土 \\
\hline 18 & Installing pillars or beams & 豎柱上梁 \\
\hline 19 & Installing the spinning machine & 經絡 \\
\hline 20 & Opening for business & 開市 \\
\hline 21 & Signing contracts & 立券 \\
\hline 22 & Trading & 交易 \\
\hline 23 & Receiving property & 納財 \\
\hline 24 & Renovating the house & 修置產室 \\
\hline 25 & Digging canals or wells & 開渠穿井 \\
\hline 26 & Installing a stone mill & 安碓磑 \\
\hline 27 & Cleaning the house & 掃屋舍 \\
\hline 28 & Leveling roads & 平治道途 \\
\hline 29 & Demolition of the house or fence & 破屋壞垣 \\
\hline 30 & Lumbering & 伐木 \\
\hline 31 & Exterminating pests & 捕捉 \\
\hline 32 & Hunting & 畋獵 \\
\hline 33 & Planting & 栽種 \\
\hline 34 & Grazing and breeding & 牧養 \\
\hline
\end{tabular}


TABLE 10.1 Thirty-seven Matters about Civil Life according to the Imperially Approved Treatise on Harmonizing the Times and Distinguishing the Directions (cont.)

No.

English

Chinese

Building graves

破土

36

Burial

安葬

37

Reburial

啟攢

regimes of temporality, an alternative understanding of global legal history is proposed as a process of translating normative knowledge between multi-temporalities (4.2).

\subsection{Temporality, Normativity, and Community of Time}

As for the temporality embodied in the Chinese calendar, it is necessary to clarify primarily that the concept of time discussed here is understood as a "social construct", ${ }^{46}$ resulting from the systematic marking, ordering, and sorting of different life moments by various agents in the religious, social, and economic spheres. It is in this sense that Richard Smith argues, with great insight, that Chinese "almanacs serve as a convenient index of Chinese hopes and fears, aesthetic preferences, ethical concerns, and forms of symbolic expression, as well as a measure of continuity and change". ${ }^{47}$ As the most basic "liturgical texts" of the Chinese, ${ }^{48}$ mantic arts that were so disputed and reproached by the missionaries can also be seen as the ordering instruments of the ritual cycle, guaranteeing the predictability of nature, imperial, and life orders, as well as harmonizing the multiple temporalities of past, present, and future.

In performing the ritual cycle, temporality endows rituals with normative qualities. Like the study of the relationship between law and time, the normativity of ritual could be formulated in two ways. The first is approaching "law as temporality", 49 in which time is interpreted as the cultural background or container of social actions. In other words, time provides rituals with a vast,

46 For a fundamental piece on social time, see Sorokin and Merton, "Social Time". For a study on the calendar from time's social dimension, see Rüpke, The Roman Calendar from Numa to Constantine, $1-5$.

47 Smith, "The Educational Role of Chinese Almanacs", 16.

48 Menegon, "The 'Teachings of the Lord of Heaven' in Fujian", 184-185.

49 For more on this approach, see Mawani, "Law as Temporality" and Mawani, "The Times of Law". 
but somewhat distant, conception of justice, through which social time is gradually materialized into a social structure. ${ }^{50}$ The second approach is that of "law's temporality", which examines the "coproduction of law and temporal norms". ${ }^{51}$ As a normative procedural system, rituals seem to be better suited than the law to inquire into the normative production of time. Specifically, through temporal rhythms, each ritual has a fixed date, a particular program, and organizes the year as a ritual cycle with the other rituals. Moreover, when considering Chinese rituals as a form of temporal norms, pointing to everyday life, it appears that the Chinese calendars can be viewed as a pragmatic manual that, though undoubtedly different from the manuals of moral theology widely applied in colonial Spanish and Portuguese America, ${ }^{52}$ can be seen as an important Chinese genre of pragmatic literature for understanding the ways in which Christianity was assimilated into different places during the process of Iberian imperial expansion.

The calendar functions as a medium of cultural synchronization that contributes to ordering the individual and the empire into a community of time. Such a medium is both technical and normative, providing an interface for achieving some degree of systemization, standardization, and modularity. ${ }^{53}$ Jörg Rüpke's study of the fasti, the ritual ordering of activities, festivities, and commemorations which followed the Roman calendar, argues that the political and judicial structure of time illustrates that religious practice was understood beyond the distinction of secularization and sacralization. ${ }^{54}$ Similarly, the Chinese calendar, through the ritualization of daily actions, weaves individuals into different organizational bodies. This shaped multiple temporal communities, as well as temporal divisions, that could not subsume oversimplified categories of rationality or superstition, but should be taken seriously as normative knowledge.

\subsection{Global Legal History as Translation of Multi-Temporality}

In terms of the regime of temporality, the encounter between Chinese and Christian conceptions of time shaped the segregation, coexistence, and overlapping of multiple communities of times. By selecting, ordering, and sorting

\footnotetext{
$5^{\circ} \quad$ For a study of justice in linear time, see Greenhouse, "Just in Time".

$5^{1} \quad$ For more on related research topics, see Beynon-Jones and Grabham (eds.), Law and Time, Introduction; Grabham et al., "Exploring Relationships Between Time, Law and Social Ordering". matic Normative Literature", for a general overview of this research field.

53 Hoof, "Calendar".

54 Rüpke, "Rationalizing Religious Practices".
} 
different temporalities, the ritual matters, however, both allow different religious communities to be kept apart as much as they present the possibility of such temporal overlapping, along with increasing encounters from local to global.

In using the term "regime", taken from François Hartog, we do not attempt to explore the more static "temporal structure of a certain culture", 55 but rather "a set of practices prescribed or adopted to regulate the rhythms of a society" 56 and, more importantly, how social constructs, such as identity, community, and order, are produced and reproduced through the making and marking of time.

On one hand, time was divided between local religious community practices and Chinese imperial precepts. Eugenio Menegon's detailed analysis of Christian community in Fuan, a remote locale of southern China, for example, vividly illustrates how Christians and people following traditional Confucian ethics positioned themselves in "two worlds" and "two times" in the 17th century, through the superposing of a new temporal rhythm according to the Roman liturgical calendar of celebrations, introduced by the Spanish Dominican friars, onto the Chinese lunisolar calendar. A similar pattern of temporal divisions was also apparent in the Muslim and Jewish communities in late imperial China. ${ }^{57}$

On the other hand, missionary activity helped harmonize time beyond local communities, both toward the Chinese imperial space as well as the global sphere of influence of the Iberian empires. The Jesuits in the service of the imperial court not only promoted the temporal unification of various regions within the Qing empire, structuring a hierarchy of time between the Qing empire and the surrounding tributary states, but also contributed to the formation of an underlying sense of global time, especially in the context of the global Iberian empires in the early modern period.

It is in this sense that the themes of global legal history, such as circulation, interaction, and connection, etc., have undoubtedly accelerated and exacerbated confrontations and reconfigurations of various communities of time, thus creating an asynchronous coexistence of multiple temporalities. In this way, global legal history could be perceived as a translation process of normative knowledge between multi-temporalities.

55 Hartog, Régimes d'historicité, 26.

56 Jordheim, "Multiple Times", 509. Please also see the special forum of "Multiple Temporalities" in the same issue.

57 Menegon, “The 'Teachings of the Lord of Heaven' in Fujia". Menegon also discusses a similar pattern of temporal divisions of the Muslim and Jewish communities in late imperial China. 


\section{Bibliography}

\section{Manuscripts}

Nanbu Xian Dangan 南部縣檔案, no. 17-00833-4.

\section{Printed Sources}

Li, Guandi 李光地, Qingding Xingli Kaoyuan 欽定星曆考原, 1713 .

Qintianjian 欽天監, Da Qing Guangxu Jiu Nian Suici Guiwei Shixianshu 大清光緒九年 歲次癸未時憲書, Harvard-Yenching Library Collection, T7190.8/635०, 1883.

Qintianjian 欽天監, Da Qing Qianlong Wushiba Nian Suici Guichou Shixianshu 大淸乾 隆五十八年歲次癸丑時憲書, Cambridge 1793: Harvard-Yenching Library Collection. Qintianjian 欽天監, Da Qing Qianlong Wushiwu Nian Suici Gengxu Shixianshu 大淸 乾隆五十五年歲次庚戌時憲書, Cambridge (MA) 1790: Harvard-Yenching Library Collection.

Qintianjian 欽天監, Xuanze Tongshu 選擇通書, 1683 .

Schall von Bell, Johann Adam, Minli Puzhu Jiehuo 民曆鋪註解惑, 1662.

Yunlu 允祿, YuzhiXieji Bianfang Shu 御制協紀辨方書, 1741.

\section{Literature}

An Shuangcheng 安雙成, “Tang Ruowang An Shimo” 湯若望案始末, in Lishi, Dangan 歷史檔案 3 (1992): 79-87.

An Shuangcheng 安雙成, “Tang Ruowang zai Hua Chuanjiao zhi De yu Shi” 湯若望在 華傳教之得與失, in Lishi, Dangan 歷史檔案 3 (1996): 72-82.

Arrault, Alain, "Les calendriers chinois: l'image du temps, le temps dans les images", in Arts Asiatiques 66 (2011): 11-32.

Beynon-Jones, Sian, and Emily Grabham (eds.), Law and Time, London 2018.

Chu, Pingyi, "Against Prognostication: Ferdinand Verbiest's Criticisms of Chinese Mantic Arts", in Lackner, Michael (ed.), Coping with the Future, Leiden 2017, 433-45o.

Chu, Pingyi, "Archiving Knowledge: A Life History of the Calendrical Treatises of the Chongzhen Reign (Chongzhen lishu)", in Extrême-Orient, Extrême-Occident 6 (2007): 159-184.

Chu, Pingyi, "Numerology and Calendrical Learning: The Stories of Yang Guangxian and Liu Xiangkui", in The Korean Journal of the History of Science 37, no. 2 (2015): 479-497.

Chu, Pingyi, "Scientific Dispute in the Imperial Court: The 1664 Calendar Case", in Chinese Science 14 (1997): 7-34.

Chunhua 春花, “Lun Qingdai Banfa Hanwen Shixianshu Shimo” 论清代颁发汉文时宪 书始末, in Manxue Luncong 满学论从 6 (2016): 170-188.

Chunhua 春花, “Lun Qingdai Banxingli ‘Shikebiao’ nei de Diming Tedian” 论清代颁 行历 “时刻表” 内的地名特点, in Mingiqng Luncong 明清论丛 15 (2015): 447-458. 
Chunhua 春花, “Lun Qingdai Manwen Shixianshu Neirong Banben ji Banfa” 论清代 满文时宪书内容版本及颁发, in Journal of Jilin Normal University (Humanities \& Social Science Edition), 1 (2018): 72-77.

Collani, Claudia von. "Astronomy versus Astrology. Johann Adam Schall von Bell and his 'superstitious' Chinese Calendar”, in Archivum Historicum Societatis Iesu 82, no. 164 (2013): 421-457.

Deiwiks, Shu-Jyuan, "The Secret Manchu Documents on the Trial of Jesuit Missionary Johann Adam Schall (1592-1666) before the Supreme Court of Beijing" in Monumenta Serica 51 (2003): 641-648.

Deiwiks, Shu-Jyuan, Bernhard Führer, Therese Geulen, and Alois Osterwalder (eds.), Europe meets China, China meets Europe: The Beginnings of European-Chinese Scientific Exchange in the 17th Century, Bonn 2014.

Dudink, Ad., "Opponents", in Standaert, Nicolas (ed.), Handbook of Christianity in China, vol. 1, Leiden 2001, 503-533.

Dunne, George, Generation of Giants: The Story of the Jesuits in China in the Last Decades of the Ming Dynasty, Notre Dame (USA) 1962.

Duve, Thomas, "Pragmatic Normative Literature and the Production of Normative Knowledge in the Early Modern Iberian Empires (16th-17th Centuries)", in Duve, Thomas and Otto Danwerth (eds.), Knowledge of the Pragmatici. Legal and Moral Theological Literature and the Formation of Early Modern Ibero-America, Frankfurt am Main 2020.

Duve, Thomas, Otto Danwerth (eds.), Knowledge of the Pragmatici: Legal and Moral Theological Literature and the Formation of Early Modern Ibero-America, Frankfurt am Main 2020.

Ge, Zhaoguang, An Intellectual History of China, Knowledge, Thought, and Belief before the Seventh Century CE, vol. 1, Leiden 2014.

Grabham, Emily, Emma Cunliffe, Stacy Douglas, Sarah Keenan, Renisa Mawani, and Amade M'charek, "Exploring Relationships Between Time, Law and Social Ordering: A Curated Conversation" in feminists@law 8:2 (2018).

Greenhouse, Carol J., "Just in Time: Temporality and the Cultural Legitimation of Law", in The Yale Law Journal 98, no. 8 (1989): 1631-1651.

Hartog, François, Régimes d'historicité. Présentisme et expériences, Paris 2014.

Hashimoto, Keizo and Catherine Jami, "From the Elements to Calendar Reform: Xu Guangqi's Shaping of Scientific Knowledge” in Jami, Catherine, Peter Engelfriet, and Gregory Blue (eds.), Statecraft and Intellectual Renewal in Late Ming China: The Cross-Cultural Synthesis of Xu Guangqi (1562-1633), Leiden 2001, 263-278.

Hashimoto, Keizo, Hsü Kuang-ch'i and Astronomical Reform: The Process of the Chinese Acceptance of Western Astronomy 1629-1639, Osaka 1988.

Hoof, Florian, "Calendar", in Beyes, Timon, Robin Holt, and Claus Pias (eds.), The Oxford Handbook of Media, Technology, and Organization Studies, Oxford 2019, 54-67. 
Hsia, R. Po-chia, "Christianity and Empire: The Catholic Mission in Late Imperial China”, in Studies in Church History 54 (2018): 208-224.

Huang Yi-Long 黃一農, "Qingchu Qintianjian zhong ge Minzu Tianwenjia de Quanli Qifu” 清初欽天監中各民族天文家的權力起伏, in Xin Shixue 新史學 2, no. 2 (1991): 75-108.

Huang Yi-Long 黃一農, “Qingchu Tianzhujiao yu Huijiao Tianwenjia de Douzheng” 清初天主教與回教天文家的鬥爭, in Jiuzhou Xuekan 九州學刊 5·3 (1993): 47-69.

Huang Yi-Long 黃一農, “Kangxichao sheji ‘Liyu’ de Tianzhujiao Zhongwen Zhushu Kao” 康熙朝涉及 “曆獄” 的天主教中文著述考, in Shumu Jikan 書目季刊 25.1 (1991): 12-27.

Huang, Yi-Long, "Court Divination and Christianity in the K'ang-hsi Era”, in Chinese Science 10 (1991): 1-20.

Huang Yi-Long 黄一農, “Tang Ruowang yu Qingchu Xili zhi Zhengtonghua” 湯若望與 清初西曆之正統化, in Wu, Jiali 嘉丽吳 and Ye Fengsa 葉鴻灑 (eds.), Xinbian Zhongguo Kejishi 新編中國科技史, vol. 2, Taipei 1990, 465-490.

Huang Yi-Long 黃一農, “Selection of Auspicious Dates and 'Calendar Lawsuit' in the K’ang-his Reign Period” 擇日之爭與 “康熙曆獄” , in QinghuaXuebao 清華學報 21, no. 2 (1991): $1-36$.

Jami, Catherine, "Revisiting the Calendar Case (1664-1669): Science, Religion, and Politics in Early Qing Beijing”, in The Korean Journal of the History of Science 37, no. 2 (2015): 459-477.

Jami, Catherine, The Emperor's New Mathematics: Western Learning and Imperial Authority During the Kangxi Reign (1662-1722), Oxford 2012.

Jordheim, Helge, "Introduction: Multiple times and the work of synchronization", in History and Theory 53, no. 4 (2014): 498-518.

Mawani, Renisa, "Law as temporality: Colonial politics and Indian settlers", in UC Irvine Law Review 4 (2014): 65-95.

Mawani, Renisa, "The Times of Law", in Law \& Social Inquiry 40, no. 1 (2015): 253-263.

Menegon, Eugenio, “The 'Teachings of the Lord of Heaven' in Fujian Between Two Worlds and Two Times", in Struve, Lynn A. (ed.), Time, Temporality, and Imperial Transition: East Asia from Ming to Qing, Honolulu 2005, 197-243.

Menegon, Eugenio, "Yang Guangxian's Opposition to Johann Adam Schall: Christianity and Western Science in His Work Budeyi”, in Malek, Roman (ed.), Western Learning and Christianity in China: The Contribution and Impact of Johann Adam Schall von Bell, SJ (1592-1666), 2 vols., Nettetal 1998, vol. 1, 311-338.

Needham, Joseph, Science and Civilisation in China. Mathematics and the Sciences of the Heavens and the Earth, vol. 3, Cambridge 1959.

Peterson, Willard J., "Calendar Reform Prior to the Arrival of Missionaries at the Ming Court”, in Ming Studies 21, no. 1 (1986): 43-61.

Ribeiro, Roberto M., and John. W. O'Malley (eds.), Jesuit Mapmaking in China: D’Anville's Nouvelle [sic] Atlas de la Chine (1737), Philadelphia 2014. 
Rüpke, Jörg, "Rationalizing Religious Practices: The Pontifical Calendar and the Law", in Tellegen-Couperus, Olga (ed.), Law and Religion in the Roman Republic, Leiden 2012, 85-106.

Rüpke, Jörg, The Roman Calendar from Numa to Constantine: Time, History, and the Fasti, New Jersey 2011.

Smith, Adam, "The Chinese Sexagenary Cycle and the Ritual Origins of the Calendar", in Steele, John M. (ed.), Calendars and Years II: Astronomy and Time in the Ancient and Medieval World, Oxford 2010.

Smith, Richard J., "The Educational Role of Chinese Almanacs: Past, present, and future", ERIC Document Reproduction Service No. ED3686o3, 1992, 16-20.

Smith, Richard, "A Note on Qing Dynasty Calendars", in Late Imperial China 9, no. 1 (1988): 123-145.

Smith, Richard, "The Legacy of Daybooks in Late Imperial and Modern China", in Harper, Donald and Marc Kalinowski (eds.), Books of Fate and Popular Culture in Early China, Leiden 2017, 336-372.

Smith, Richard J., Chinese Almanacs, Oxford 1992.

Smith, Richard J., Mapping China and Managing the World: Culture, Cartography and Cosmology in Late Imperial Times, London 2013.

Sorokin, Pitirim A., Robert K. Merton, "Social Time: A Methodological and Functional Analysis", in American Journal of Sociology 42, no. 5 (1937): 615-629.

Struve, Lynn A. (ed.), Time, Temporality, and Imperial Transition: East Asia from Ming to Qing, Honolulu 2005.

Wang Yuanchong 王元崇, “Calendar Books of the Qing Dynasty and the Formation of a Modern, Unified and Multinational China” 时宪书与中国现代统一多民族国家的 形成, in Social Science in China 中国社会科学 (5) 2018, 185-203.

Xu Guanqi 徐光启, Zhi Li Yuan Qi 治历缘起, Shanghai 2009.

Zhang, Qiong, Making the New World Their Own: Chinese Encounters with Jesuit Science in the Age of Discovery, Leiden 2015.

Županov, Ines G., Pierre Antoine Fabre (eds.), The Rites Controversies in the Early Modern World, Leiden 2018. 